\title{
The Long-Run Stock Performance of Privatization IPOs
}

\author{
Seung-Doo Choi \\ Dongeui University, Korea \\ Sang-Koo Nam \\ Korea University, Korea
}

This paper compares the long-run buy-and-hold returns of privatization initial public offerings (IPOs) to those of the domestic stock markets of respective countries using a sample of 241 privatization IPOs from 41 countries. The evidence indicates that the privatization IPOs significantly outperform their domestic stock markets if the returns are equally-weighted while value-weighted returns show a sharp reduction in performance. However, there are substantial variations in the long-run performance of privatization IPOs across industries, issuing countries, issue period, and the origin of commercial law of the country. This paper also analyzes the cross-sectional determinants of the long-run buy-and-hold returns of privatization shares. The results indicate that the long-run performance of privatization IPOs is significantly related to the proxies of policy uncertainty, consistent with the signaling models of Perotti (1995). Such effects appear to be overwhelming in the earlier post-IPO period, while the traditional market factors become more important as the policy uncertainty disappears over time. The institutional features of the country such as accounting standards, origin of commercial law, and corporate governance scheme also affect the return performance of privatization issues (JEL: G32).

Keywords: privatization, IPO, policy uncertainty, CAR, BHAR

\section{Introduction}

Privatization has become the popular policy of choice in both industrialized and developing countries. The U.K. based database

\footnotetext{
* This work was supported by Dong-eui University Grant (2006AA059). We would like to thank Inmoo Lee, Paul Malatesta, William Megginson, Enrico Perotti, and Jay Ritter for their helpful comments.
}

(Multinational Finance Journal, 2006, vol. 10, no. 3/4, pp. 223-250)

(C) Multinational Finance Society, a nonprofit corporation. All rights reserved. DOI: $10.17578 / 10-3 / 4-3$ 
Privatisation International estimates that 40 governments from around the world have raised 37 trillion dollars through share offerings and direct sales over the period $1977-1997$. The proceeds roughly equal to the 'world gross domestic products' of 1991 reported in the World Development Report. The privatization programs have been widely promoted based on the evidence that privatization serve to improve the efficiency and profitability of a firm. Megginson, Nash, and van Randenborgh (1994), Boubakri and Cosset (1998), D'Souza and Megginson (1999), and Dewenter and Malatesta (2001) report that there are significant improvements in firm output, efficiency, and profitability following privatization.

These findings are consistent with the predictions of the property rights theory, advanced by Alchian (1965). He suggests that state-owned enterprises (SOEs) tend to be less efficient and less profitable than privately-owned enterprises. Perotti (1995) argues that, under public ownership, firm profits are independent of managerial efforts because stakeholders can force the government to grant them a share of the output regardless of their endeavors; managers therefore have no incentive to exert themselves. In contrast, once the firm is privatized, managers have an increased incentive to exert themselves as a result of the private owner's residual rights of control.

Megginson, Nash, Netter, and Schwartz (2000) document that average market-adjusted, "equally-weighted" cumulative abnormal returns (CARs) of privatization issues are significantly positive over five-year holding periods. Dewenter and Malatesta (2001) also confirm these results by examining buy-and-hold abnormal returns (BHARs). Their findings are in sharp contrast with those of Ritter (1991) who reports short-run over-reaction and long-run under-performance in the U.S. IPO market. However, Fama (1998) and Lyon, Barber, and Tsai (1999) argue that the commonly used methods for computing long-run abnormal returns tend to yield misspecified test statistics. Barber and Lyon (1997) also indicate that CARs are a biased predictor of BHARs. More recently, Brav, Geczy, and Gompers (2000) have shown that IPO issuer returns are similar to benchmarks matched on firm size and book-to-market ratios and that many of the long-run return anomalies are manifestations of the same pattern. Mitchell and Stafford (2000) assert that value-weighting the abnormal returns of the issuer reduces measured abnormal performance. It would therefore appear that the assertion, "privatization IPOs outperform the market," may be unwarranted. 
The major motivation of this paper is to estimate the long-run stock returns for privatized firms and to analyze the determinants of privatization returns. We estimate the long-run returns to investors using a comprehensive sample of 241 privatization IPOs from 41 countries during the period $1980-2000$. Tests are based both on CARs and BHARs techniques. We confirm the findings of earlier studies that privatization IPOs outperform the respective domestic market if we equally weight the returns. The reverse is true if the long horizon returns are value-weighted, however. Moreover, there are substantial variations in the long-run performance across industries and issuing countries. The time series behavior of long-run BHARs of privatization shares tends to be consistent with the signaling model of Perotti (1995). The long-run performance of privatization IPOs is positively related to the signaling variables of stake sold (percentage of the firm's capital offered) at the initial offer, the degree of policy uncertainty in the industry, and to market variables such as beta, book-to-market ratio, and size of the firm. Furthermore, the long-run privatization returns can be explained by the institutional features of the issuing countries which in turn seem to depend on the accounting standards, income level, and the origin of commercial law of the country.

This paper is organized as follows. Section II summarizes the literatures dealing with financial performance of privatization IPOs. Section III briefly reviews the statistical issues concerning the estimation of long-run abnormal returns of event firms. The sample selection procedure and data are described in section IV. Section V presents our findings on the long-run abnormal returns of privatization IPOs and section VI puts forward our conclusions.

\section{Operating and Financial Performance of Privatization}

Fortune (2002) reports that 268 of the world's largest 500 corporations are from outside the U.S. and that of these 268,44 privatized SOEs account for 9.8 percent of total revenue, 29.6 percent of profit, 87 percent of assets, and 16.3 percent of employees for non-U.S. nations. It is widely believed that equity issuance by governments has had a profound impact on the liquidity and total capitalization of domestic and international stock markets. Megginson et al. (1994) report that privatization IPOs are almost always the largest equity offerings in the history of most domestic capital markets and usually cause a significant 
increase in the number of shareholders. Megginson, Nash, Netter, and Schwartz (2000) report that 158 privatization IPOs from 1981 to 1996 had a mean offer size of 1,044 million dollars. In contrast, Loughran, Ritter, and Rydqvist (1994) report that the mean offer size of 5,450 private sector IPOs from 25 countries during 1960 - 1990 was 22 million dollars.

How, then, does the stock market react to such a surge of privatization issues? The privatization IPOs were successful for investors because the privatization equity offers tended to be made at highly discounted fixed-prices. Choi and Nam (1998) show that the average level of underpricing in privatization IPOs is significantly higher than that of private sector IPOs. This is somewhat puzzling, since the uncertainty about the earning prospects of the SOEs is fairly low and therefore, the traditional theory of information asymmetry predicts less underpricing for privatization IPOs.

Another empirical question rests on the long-run performance of privatized firms. Ritter (1991) reports short-run over-reaction and long-run under-performance in the U.S. IPO market. A large number of follow-up studies confirm that the under-performance of IPOs is a global phenomenon. ${ }^{1}$ In contrast, Dewenter and Malatesta (2001) find statistically significant positive long-run BHARs in their sample of 102 privatization issues from eight countries. Using a larger sample, Megginson et al. (2000) also report significantly positive long-run abnormal returns for a sample of 158 privatization IPOs conducted in 33 countries compared to domestic market indices, the Financial Times World Index, the S\&P 500 index, and portfolios of American firms in the same industry. ${ }^{2}$

These results are theoretically predicted by Perotti (1995) and Boycko, Shleifer, and Vishny (1996) and are consistent with the economic success of privatization, empirically supported by Megginson et al. (1994), Boubakri and Cosset (1998), and Dewenter and Malatesta (2001). They show that privatized firms increase real sales, become more profitable, increase their capital investment spending, and improve their operating efficiencies. They also report significant improvements

1. See Megginson, Nash, Netter, and Schwartz (2000) for more details.

2. See Megginson and Netter (2001) for more information on long-run stock returns of privatized IPOs. 
in firm output, efficiency, and profitability following privatization. ${ }^{3}$ However, it is too early to conclude regarding the long-run stock performance of privatization IPOs. This is because of potential problems in long-term stock performance studies.

\section{Test of Long-run Returns}

One of the most intensively discussed issues in financial economics in recent years has been the long-run return earned by investors who purchase the shares of firms. It appears that analyzing long-run abnormal return can be very difficult and misleading. Lyon et al. (1999) show in their random sample simulation that the commonly used methods for estimating long-run abnormal returns tend to yield misspecified test statistics. Barber and Lyon (1997) find that long-horizon returns are positively skewed, leading to an inflated significance level for lower-tailed tests and a loss of power for upper-tailed tests. In their follow-up study, Lyon et al. (1999) recommend the use of bootstrapped skewness-adjusted $t$-statistics to control for the skewness bias when long-horizon returns are calculated using the BHAR method.

Fama (1998) argues that a spurious abnormal return of $x$ percent per month eventually becomes statistically reliable in long-horizon abnormal returns, unless expected differences between the return on event firms and on benchmarks are close to zero. The statistical problems will be worsened if the abnormal returns are obtained by compounding (e.g., BHARs) rather than summing (e.g., CARs). Mitchell and Stafford (2000) show that value-weighting the abnormal performance of issuers reduces the measured abnormal performance. They also indicate that the BHAR method ignores the problems arising from calendar (and industry) clustering which inflate the statistical significance of economically trivial events. They strongly recommend the use of CARs and Fama-French (1993) calendar time regression. However, Loughran and Ritter (2000) show that the Fama-French approach is the uniformly least powerful test of market efficiency. Ritter and Welch (2002) show that whether or not one uses BHARs or

3. In contrast Jain and Kini (1994) and Mikkelson, Partch, and Shah (1997) report that long-run return performance is accompanied by poor financial accounting performance post-IPO relative to pre-IPO performance in the U.S. IPO market. 
TABLE 1. Sample Description

\begin{tabular}{|c|c|c|c|c|}
\hline $\begin{array}{l}\text { Country } \\
\text { (issue period) }\end{array}$ & $\begin{array}{l}\text { Sample } \\
\text { Size }\end{array}$ & $\begin{array}{l}\text { Average } \\
\text { Stake Sold } \\
(\%)\end{array}$ & $\begin{array}{l}\text { Average First } \\
\text { Day Return } \\
(\%)\end{array}$ & $\begin{array}{l}\text { Average } \\
\text { Proceeds in } \\
\text { Millions of } \\
\text { U.S. Dollar }\end{array}$ \\
\hline China (92-00) & 13 & 26.4 & -0.0 & 842 \\
\hline Egypt (94-95) & 5 & 26.6 & 72.0 & 25 \\
\hline Low income* & 22 & 25.7 & 33.2 & 610 \\
\hline Argentina (91-94) & 4 & 31.3 & 23.0 & 1,462 \\
\hline Brazil (91-97) & 3 & 82.0 & & 628 \\
\hline Greece (96-98) & 3 & 15.9 & 8.0 & 275 \\
\hline Hungary (92-98) & 11 & 39.9 & 12.8 & 180 \\
\hline Indonesia (94-96) & 4 & 28.5 & 16.7 & 957 \\
\hline Malaysia (85-99) & 12 & 29.0 & 47.1 & 432 \\
\hline Morocco (93-96) & 5 & 32.3 & 4.0 & 75 \\
\hline Philippines (91-94) & 3 & 13.3 & 53.2 & 238 \\
\hline Poland (91-98) & 29 & 52.2 & 891 & 84 \\
\hline Thailand (89-97) & 7 & 12.8 & 43.0 & 156 \\
\hline Middle income** & 83 & 40.0 & 50.8 & 327 \\
\hline Australia (91-98) & 9 & 72.1 & 13.9 & 2,030 \\
\hline Austria (87-95) & 10 & 42.9 & -2.9 & 220 \\
\hline Canada (86-96) & 8 & 67.0 & 81 & 724 \\
\hline Finland (94-98) & 4 & 22.2 & 1.5 & 675 \\
\hline France (86-00) & 11 & 62.9 & 9.6 & 3,910 \\
\hline Germany (88-98) & 7 & 36.2 & 12.6 & 2,935 \\
\hline Italy (94-99) & 7 & 39.8 & 13.4 & 4,517 \\
\hline Japan (87-98) & 5 & 41.1 & 21.3 & 12,476 \\
\hline Korea, R. (88-98) & 4 & 19.4 & 119.5 & 2,128 \\
\hline New Zealand (92-99) & 3 & 27.4 & 24.1 & 866 \\
\hline Norway & 3 & 54.3 & 6.3 & 237 \\
\hline Portugal (89-97) & 8 & 42.4 & 20.6 & 727 \\
\hline Singapore (85-93) & 8 & 27.2 & 38.0 & 437 \\
\hline Spain (87-99) & 6 & 42.8 & 32.7 & 798 \\
\hline Sweden (93-00) & 4 & 39.1 & 7.0 & 2,865 \\
\hline Taiwan (91-96) & 4 & 13.1 & 42.5 & 119 \\
\hline U.K. (81-96) & 27 & 89.2 & 32.9 & 2,071 \\
\hline High income ${ }^{* * *}$ & 136 & 53.5 & 21.4 & 2,192 \\
\hline Full Sample & 241 & 46.5 & 32.8 & 1,405 \\
\hline
\end{tabular}

Note: This table reports sample size, mean stake sold at the initial offer, average first day return and mean proceeds of issuing countries. Proceeds are restated into 2001 U.S. dollars using the change in the U.S. consumer price index. Sample countries are partitioned by the gross national product per capita, reported in World Development Report (1997).

* This group also includes an observation from Pakistan and Kenya, and two observations from India. ** This group includes an observation from South Africa and Venezuela. *** The high income countries group also includes an observation from Belgium, Denmark, Ireland, Israel, Switzerland, and the U.S., and two observations from the Netherlands.

Fama-French regressions matters little. In short, there are still great debates on what is the best way to examine long-run stock performance. 
Therefore, it is important to check whether previously documented results on long-run stock performance of privatization IPOs are robust to the methodologies used. In addition, the robustness check will also provide further information about whether the stock market values privatized firms without any systematic bias after IPOs. To address these issues, this study estimates the long-run stock performance of privatization IPOs using both the CAR and BHAR method to check the sensitivity of the results. In calculating average abnormal returns, we use both equally- and value-weighted averages.

\section{Data and Methodology}

\section{Data and Descriptive Statistics}

The initial sample includes 445 candidate privatization IPOs from 55 countries taking place between 1977 and 2000. The main sources of data are the privatization database, Privatisation International, Jones et al. (1999), Dewenter and Malatesta (2001), and the privatization database maintained by the World Bank. Data collected for each privatization IPO include the name of the firm, its industry classification, the issuing country, offer dates, the issue size, the first day return, the percentage of the firm's capital in the initial offer, and the percentage of the offer allocated to foreigners. For those transactions representing IPOs, local currency denominated stock price, return series and relevant country stock market indices are collected from Datastream International. To be included in the final sample, the stock returns are required to be recorded in Datastream International for at least one year after the initial offer. Because Datastream International is a customer-based commercial database, it tends not to provide data on smaller issues and issues from thin markets.

Our final sample of privatization IPOs, as described in table 1, consists of 241 initial equity issues, which collectively raised 339 billion U.S. dollars for 41 countries. The proceeds are restated as 2001 U.S. dollars using the change in the U.S. consumer price index. The mean offer size is 1,405 million U.S. dollars, compared to that of 1,044 million dollars reported by Megginson et al. (2000) for their sample of 158 privatization IPOs. This difference appears to arise from the fact that our sample includes the huge privatization IPOs conducted since late 1997. Interestingly enough, table 1 shows that the frequency of 
privatization IPOs and mean of stake sold are closely related to the income level (gross national product per capita) of the issuing country. The World Bank classifies 49 countries as low-income, 60 countries as middle-income, and 26 countries as high-income economies. Table 1 shows that 5 countries in the low-income bracket have conducted 22 privatization IPOs worth 12 billion dollars in total while 24 of the countries in the high-income group have conducted 136 privatization IPOs worth 241 billion dollars. The mean stake sold at initial offer is 25.7 percent for low-income, 40.0 percent for middle-income, and 53.5 percent for high-income economies. However, more privatization IPOs are expected to take place in the less developed countries over the next decades since the number of issues from low to middle-income economies have been rapidly increasing recently.

Table 2, using cohort year as in Ritter and Welch (2002), shows that the privatization IPOs are concentrated in the early 1990s with a sharp decrease in recent years, especially during the so-called Internet Bubble period of $1999-2000$. The table indicates that the "hot issue market" for privatization IPOs was the early 1990s. ${ }^{4}$ There were only 13 privatization IPOs in $1999-2000$ period. In addition, table 2 also reports distributions across 5 industries, financial, manufacturing, natural resources, services and utilities. The industry classification is based on the two-digit U.S. standard industry classification code. Average first day return, average proceeds and average market values of the privatization IPOs are also reported in table 2. Utilities and financial firms are well represented in our sample. There are 39 financial firms and 72 utilities firms in the sample. Consistent with previous studies that document high first day returns of privatization IPOs (e.g., Choi and Nam [1998]), the average (median) first day returns is 32.8 percent (13.6 percent). They are significantly different form zero.

The average market value of our privatization IPO firms is 6.3 billion dollars, which is far greater than the average market capitalization of private firms. For example, Corwin, Harris, and Lipson (2004) show that the average market capitalization of 220 IPOs listed on the New York Stock Exchange from 1995 to 1998 is 689 million dollars. However, average proceeds and market value of the issuing firm tend to

\footnotetext{
4. There are many privatization IPOs in earlier 1990s compared to in 1980s and in 1994 - 1996. It would appear to someone that the data suffer from clustering. This would make interpretation a bit cautious.
} 
increase over time. Eckbo, Masulis, and Norli (2000) indicate that the issuer underperformance is, by and large, driven by stocks of relatively small issuers. Ritter and Welch (2002) report that small growth firms or penny stocks have been the worst performing category of shares. They assert that penny stock IPOs had high first day returns and exceptionally low long-run returns. They find the three-year market-adjusted return and style-adjusted return on IPO amounts to -12.4 and -5.1 percent, respectively. Fortunately, however, table 2 shows that our sample is free of the problems arising from penny stock effect; nor does it appear to suffer from industry or calendar clustering both of which would seriously contaminate the estimation of long-run stock returns. Therefore, the CARs or BHARs estimated from our sample are also free from the worries suggested by Mitchell and Stafford (2000).

\section{Methodology}

We calculate privatization returns over holding periods of one through five years following the offer. The long-horizon returns are based on monthly returns, and they are calculated using the closing price of the first trading date. We adjust the stock return by subtracting the contemporaneous return on a domestic market index from the return on each privatized firm. We employ comprehensive, value-weighted Datastream Total Market Index for the sample countries to capture the general movement of the market. Specifically, the long-horizon buy-and-hold abnormal returns are calculated as follows:

$$
B H A R_{i t}=\prod_{t=0}^{\tau}\left(1+R_{i t}\right)-\prod_{t=0}^{\tau}\left(1+R_{M C t}\right)
$$

where, $t$ is the number of months from the first trading day; $\tau$ is the period of investment in months $(\tau=12,36,60) ; R_{i t}$ is the return on security $i$ in month $t$, and $R_{M C t}$ is the market return of the country in month $t$.

For the calculation of BHAR, we first calculate monthly buy-and-hold return (BHR) by compounding daily returns calculated using total return index in the Datastream over each calendar month. We then calculate annual BHRs of sample firms by compounding monthly BHRs over each corresponding 12-month horizon. After calculating annual BHRs of sample firms and market indices, we calculate average annual BHRs for both sample firms and market indices. 


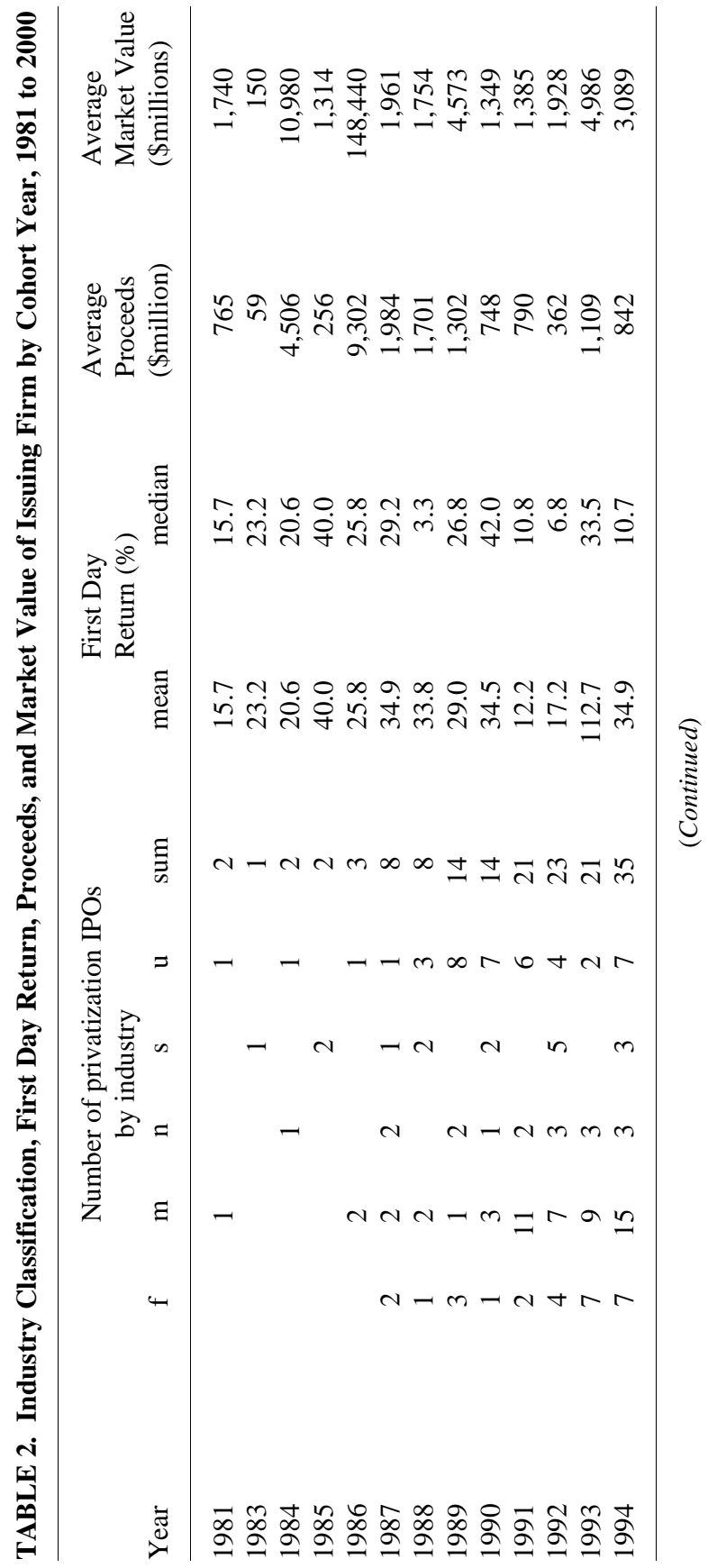




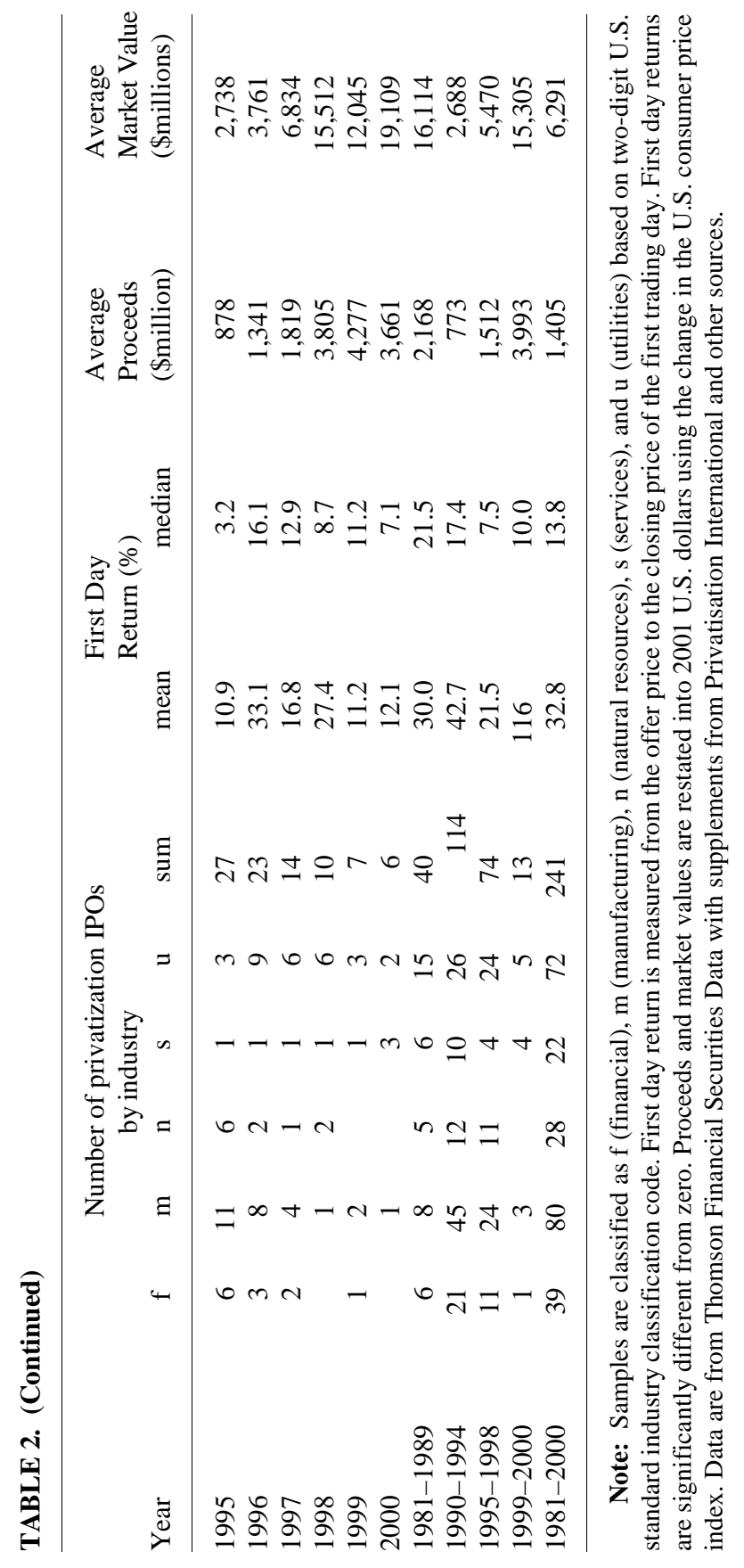


We calculate the average annual BHRs using both equally and value-weighting methods. Weights used in value-weighting are calculated based on the market capitalization that is converted in to U.S. dollars in terms of 2001 U.S. purchasing power. We then calculate three- and five-year BHARs by compounding annual BHRs over the relevant number of years. This implies that we assume annual rebalancing in calculating multi-year average BHRs since we are changing weights of each stock every year. Finally, one-, three-, and five-year rebalanced value-weighted BHARs are calculated by subtracting the corresponding average BHRs of market indices from the relevant average BHRs of our sample firm. In addition, we compute unrebalanced value-weighted BHARs which are assumed to be held from the offer date to the relevant number of years. Let $w_{i}$ denote stock $i$ 's weight in forming the average holding period return. The effective holding period for stock $i$ is $T_{i}$ which is five years or the time until delisting, whichever comes first. The percentage weighted average holding period returns across a sample of $\mathrm{N}$ stocks is given by:

$$
W R \equiv \sum_{i=1}^{N} w_{i}\left[\sum_{t=\tau i}^{T i}\left(1+R_{i t}\right)-1\right]
$$

For the calculation of CARs, we calculate daily abnormal returns by subtracting daily returns of market indices from those of sample firms. We then cumulate daily abnormal returns over the corresponding number of days to calculate CARs over different time horizons. We then calculate both equally- and value-weighted CARs.

\section{Results}

\section{Tests of Zero Mean CARs and BHARs for Privatization IPOs}

This section presents the long-horizon return results for our samples of privatization IPOs. Table 3 reports summary statistics for the long-horizon CARs and BHARs for the 241 privatization IPOs in the sample. Results in panel A of table 3 reject the null hypothesis of no difference in holding period returns of privatization IPOs and the market returns of their home countries equally-weighted CARs are significantly and consistently positive over each holding period, while equally-weighted BHARs are significantly positive in the earlier period, 
but become insignificant as time elapses. Over the five-year period, privatization IPO firms have outperformed their domestic markets by 38.8 percent, on average. ${ }^{5}$ The median returns are much smaller, but nevertheless remain positive over each holding period. CARs are more significant than BHARs over all horizons. The results are consistent with those of Barber and Lyon (1997) who report that BHARs are positively skewed, leading to an inflated significance level for lower tailed tests and a loss of power for upper tailed tests. Conventional $t$-statistics for each holding period indicate that the privatization IPOs significantly outperform their home capital market. The $t$-values are much lower than those of Megginson et al. (2000) who report that 5-year CARs amount to 45.4 percent.

Previous researches show that the sample distribution of stock returns follows asymmetric, heavy-tailed distribution. Therefore we draw 1,000 bootstrapped re-samples from the original sample of size $n_{b}$ $=n / 4$ for each holding period, as Lyon et al. (1999) recommend, and calculate bootstrapped significance level for the skewness-adjusted $t$-statistic. Bootstrapped results lend support for the assertions of Fama (1998) and Lyon et al (1999) that conventional $t$ test leads to an inflated significance level for lower tailed tests and a loss of power for upper tailed tests. Test results based on the bootstrapped skewness-adjusted $t$-statistics, suggested by Lyon et al. (1999) confirm our conclusions of significant difference between privatization and market returns.

However, panel 2 and 3 of table 3 tells a different story. Unrebalanced value-weighted returns which are assumed to be held from the offer date are significantly positive in the one-year, but null in the three- and five-year holding periods. However, rebalanced BHARs are much higher than unrebalanced ones, but nevertheless remain insignificantly positive in the three- and five-year holding period. This is similar to the results based on private IPOs. Brav, Geczy, and Gompers (2000) and Mitchell and Stafford (2000) document that IPO firms underperform broad market benchmarks by a wide margin on an equal weight basis, while value weighting reduces the abnormal performance by more than half. This clearly shows that the long-run

5. To check the robustness of the results, we compute equally-weighted CARs and BHARs using a sample of 218 privatization IPOs which have celebrated the fifth anniversary of their IPOs. One-, three-, and five-year CARs (BHARs) are $0.1166(0.1525), 0.1712$ $(0.3310)$, and $0.2569(0.3830)$, respectively. Significance levels are similar to those reported in panel A of table 3. 


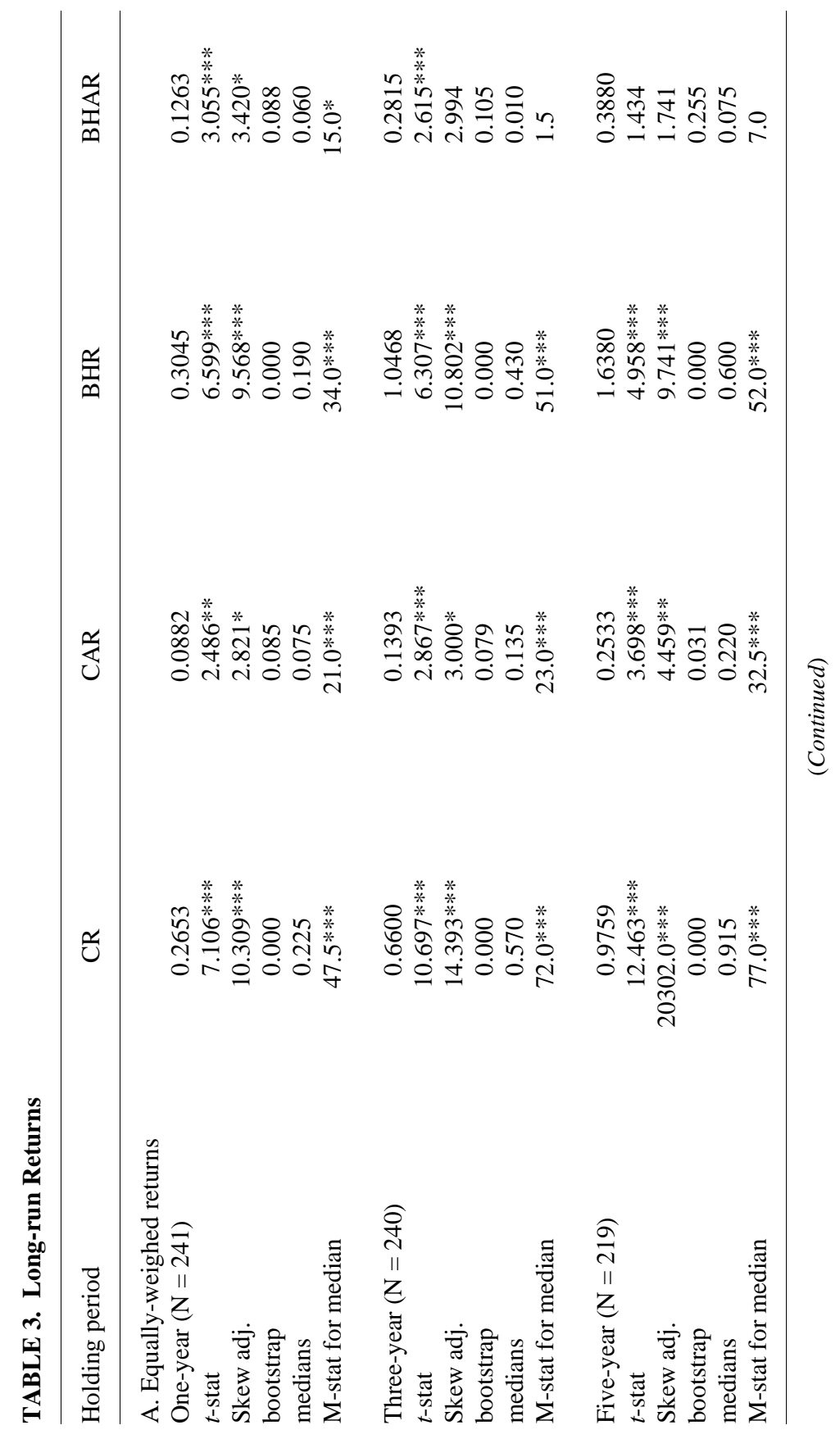




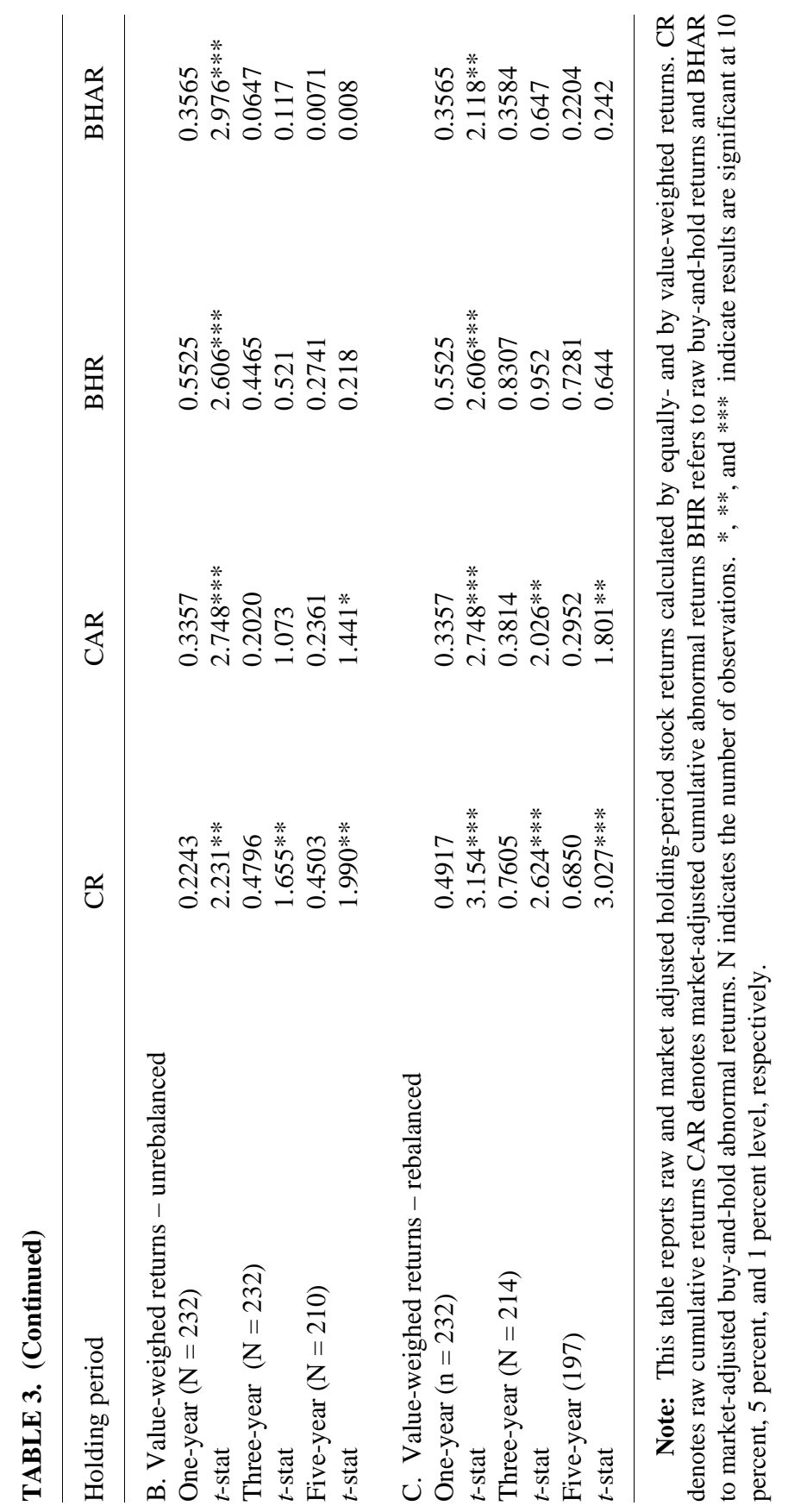


returns are very sensitive to the methods used to measure average abnormal returns.

For a five-year horizon, even equally-weighted average of five-year BHARs relative to the market index is not significant, while that of five-year CARs are significantly positive. The equally-weighted five-year BHAR is insignificant 38.8 percent while unrebalanced value-weighted five-year BHAR is only 0.7 percent. In contrast, Dewenter and Malatesta (2001) report significantly positive 88 percent of five-year BHARs for their sample of 78 privatization IPOs. Similarly, Megginson et al. (2000) report significantly positive equally-weighted average five-year BHAR of 91 percent. The primary reason for different results in our study compared to previous studies is likely to be an extended sample size. Our sample includes privatization IPOs during 1977 and 2000 and covers more IPOs even during the period of 1981-1996, the sample period used by Megginson et al. (2000). The inclusion of more sample IPOs seems to reduce the significance of 5-year BHARs.

In sum, results in table 3 show that privatized firms outperform their domestic market over one-year on value-weighted basis or three-year horizon on equally-weighted basis, but might not over longer horizons. Given previous results that privatization IPO firms improve their operating performance over three years after IPOs (e.g., Megginson et al. [1994]), the market seems to be slow in correctly evaluating the efficiency gains and profitability improvements from privatization during the first year after IPOs but it seems to catch up by the end of the third year. This suggests that being different from private IPOs, privatization IPOs are offered not to take advantage of investor optimism in the market. This is supported by the fact that the number of privatization IPOs has gone down during the internet bubble period when investor optimism was prevalent.

\section{Univariate Tests of Return Performance by Issue Characteristics}

The substantial difference between the mean and median returns of CARs and BHARs suggests that privatization returns might differ in their sample-specific characteristics. To analyze the sources of return difference, we partition the sample by sample specific attributes such as; issue period, industry classification of the privatized firms, the income level (GNP per capita), law origin, and a score for the accounting standards of the issuing country. 
The income level of the issuing country may influence the privatization returns. Shleifer and Vishny (1997) assert that the corporate governance scheme of private firms is more sophisticated, and thus market discipline on inefficient managers more severe, in industrialized countries than less developed countries. Moreover, high-income countries tend to privatize SOEs to improve the operating efficiency of the firm, not to maximize proceeds, as Jones et al. (1999) point out. Sample firms are classified as high, middle, and low-income countries, based on the World Development Report (1997). High income category is further subdivided into European and non-European based on the location of the issuing countries.

Panel A of table 4 indicates that the privatization shares from high-income countries persistently outperformed their capital markets. Their performance, measured by equally-weighted BHAR, tends to increase with holding period. In contrast, the privatization returns of middle- and low-income countries also outperform their domestic capital markets in the earlier period but decline in later periods, even underperforming the market. These results are consistent with the assertions of Shleifer and Vishny (1997). ${ }^{6}$

Earlier studies on privatization have shown that efficiency gains are associated with the industry in which the firm operates. Vickers and Yarrow (1991) review previous empirical studies on the effect of privatization and conclude that the efficiency of privatized firms in the competitive industries improves significantly, while that of the firms in monopolistic or protected industries such as electricity and telecommunications does not. Megginson et al. (1994) have shown that privatized firms improve their operating efficiencies with a more substantial improvement seen in utilities. Thus, it appears that the efficiency arguments are contradictory. To explore the effect of industry on the privatization, we partition the sample into five subgroups based on the two-digit Standard Industry Classification (SIC) code. Specifically, code 01-13 denote natural resources; code 14-39 manufacturing, code 40, 48, and 49 utilities, code 60-67 financials, and others services.

Panel B of table 4 shows that the privatization returns are closely associated with the industry classification of the privatized firms. The privatization returns of services and utilities are significantly and

6. Although not reported, a standard ANOVA was conducted. ANOVA Duncan tests are used to identify any statistically significant pair wise differences. 
TABLE 4. Long-run BHARs for Partitioned Samples

\begin{tabular}{|c|c|c|c|}
\hline Holding period & One-year & Three-year & Five-year \\
\hline \multicolumn{4}{|l|}{ A. By Income Level } \\
\hline High, Europe (98) & 0.1651 & $0.4678 A$ & $0.8245 A$ \\
\hline High, non-Europe (47) & $0.3302 A$ & $0.3057 A$ & $0.9409 A$ \\
\hline Middle (74) & 0.0119 & 0.1689 & $-0.3800 B$ \\
\hline Low (22) & $-0.1341 B$ & $-0.3268 B$ & $-0.3856 B$ \\
\hline F - value & $3.75^{* *}$ & $1.51 *$ & $1.71 *$ \\
\hline \multicolumn{4}{|l|}{ B. By Industry } \\
\hline Financial (50) & $0.0012 B$ & 0.2110 & 0.4695 \\
\hline Manufacturing (80) & 0.0935 & 0.1807 & $-0.8162 B$ \\
\hline Natural Resource (28) & 0.0871 & -0.0671 & $1.8185 \mathrm{~A}$ \\
\hline Services (23) & 0.0833 & 0.2329 & 0.7737 \\
\hline Utilities (70) & $0.2781 \mathrm{~A}$ & 0.5891 & $0.9500 A$ \\
\hline F - value & $1.70 *$ & 1.72 & $2.94 * *$ \\
\hline \multicolumn{4}{|l|}{ C. By Law Origin } \\
\hline English (82) & $0.3009 A$ & 0.6424 & 1.379A \\
\hline French (63) & 0.0738 & -0.0275 & 0.026 \\
\hline German (31) & 0.2142 & 0.3006 & 0.220 \\
\hline Scandinavian (12) & $-0.0408 B$ & -0.0817 & -0.015 \\
\hline Soviet (53) & $-0.0991 B$ & 0.1175 & $-0.783 B$ \\
\hline F - value & $3.81 * *$ & 1.80 & $2.39 *$ \\
\hline \multicolumn{4}{|l|}{ D. By Issue Period } \\
\hline 1981-1989 (40) & 0.2140 & 0.4287 & 0.9311 \\
\hline $1990-1994(114)$ & 0.0957 & 0.3793 & 0.3024 \\
\hline 1995-1998 (74) & 0.1570 & 0.1082 & 0.1687 \\
\hline $1999-2000(13)$ & -0.0669 & -0.2215 & 15201 \\
\hline $\mathrm{F}$ - value & 0.79 & 0.89 & 0.35 \\
\hline \multicolumn{4}{|c|}{ E. By Accounting Standards } \\
\hline High (55) & $0.2304 \mathrm{~A}$ & 0.6691 & 1.1017A \\
\hline Upper middle (50) & $0.2790 A$ & 0.3912 & 0.9959 \\
\hline Lower middle (71) & 0.1152 & 0.0452 & 0.1683 \\
\hline Low $(65)$ & $-0.0705 B$ & 0.0915 & $-0.5852 B$ \\
\hline $\mathrm{F}$ - value & $3.62 * *$ & 1.84 & $208 *$ \\
\hline
\end{tabular}

Note: This table reports buy-and-hold abnormal returns of privatization IPOs. The BHARs of the privatization IPOs are calculated by subtracting domestic stock market returns from the stock returns for the same period. Income level of the sample countries is taken from World Development Report (1994). Industry classification is based on two-digit standard industry classification code. Information on law origin and accounting standards is taken from La Port et al. (1998). Issue period of the sample is partitioned according to the classification in Ritter and Welch (2002). The number of observation is given in parentheses. Bold A indicates high return group and italic $B$ low return group. $*$ and $* *$ indicate results are significant at 10 percent and 5 percent level, respectively. 
persistently higher than their domestic market returns. Investor returns for financial firms are insignificantly different from their market return over the five-year holding period. However, firms in manufacturing industry outperform their respective markets in the earlier period while they underperform by a wide margin in the later period. ANOVA Duncan test shows that natural resource and utilities firms outperform those in the financial and manufacturing sectors at the 5 percent significance level over five-year holding period.

La Porta, Lopez-de-Silanes, Shleifer, and Vishny (1998) show that the origin of commercial law of a country is closely related to its economic performance. Panel $\mathrm{C}$ of table 4 indicates that the measures taken from La Porta et al. are closely related to the performance of privatized companies. Firms in the English law category consistently outperform domestic markets, while those in the Soviet law category, which is a newly classified category in this research, severely underperform domestic markets. Firms in French law category do not outperform their domestic market.

Issue periods are classified as per Ritter and Welch (2002), who summarize that firms go public in response to favorable market conditions and that issuing volume drops precipitously following stock market drops. Table 2 confirms these phenomena. They assert that IPO volume is related to various forms of market irrationality and to the long-runs performance of the IPO stocks. Panel D of table 4 confirms this point. The period 1990 - 1994, the "hot issue" market for privatization, records lower than average 5-year performance overall. However, ANOVA Duncan tests indicate no statistical difference in the privatization returns among those subsamples, reflecting the fact that long horizon BHARs are typically contaminated with outliers which inflate standard errors and reduce the significance of the test statistics. Brav et al. (2000) also documents that long-run returns are sufficiently affected by noise that any statistical inference is difficult.

La Porta et al. (1998) also show that the accounting standard index of a country is closely related to the performance of its economy. We use the index of the Center for International Financial Analysis and Research (La Porta et al. [1998]) to group countries into quartiles from lowest to highest level of accounting standards. Panel E of table 4 indicates that firms in countries with the highest standard persistently outperformed their capital markets. Their performance tends to increase with holding period. ANOVA Duncan test shows that firms from countries with high level of accounting standards significantly 
outperform those from low-scored countries at the 5 percent significance level over one-year holding period and at 10 percent level over five-year holding period.

\section{Determinants of Privatization Returns}

The results in table 2 indicate that privatization IPO firms are typically bigger than private IPO firms and raise substantially larger amounts than private IPO firms. However, the first day returns are on average very high, which is not expected from asymmetric information based explanations of IPO underpricing. The common prediction of various asymmetric information based explanations is that as information asymmetry increases, first day returns are likely to increase as pointed out in Ritter and Welch (2002) Since privatized firms are on average bigger with a longer history and many are from more stabilized industries, we would expect that there is less information asymmetry in privatization IPOs.

Choi and Nam (1998) and Jones et al. (1999) indeed show that the first day returns of privatization IPOs can be explained by the signaling models of Perotti (1995) that is specific to privatization IPOs, and asymmetry information based explanations do not work well. Perotti (1995) argues that privatization IPOs are underpriced to signal the government's determination to eliminate policy uncertainties regarding privatization plans. If high first day returns of privatization IPOs are not due to asymmetric information, rather due to credibility of government's policies, there are no compelling reasons to expect long-term abnormal returns of privatization IPOs unless the market systematically under or overestimate the efficiency gains and profitability improvements of privatized firms even when there is not much information asymmetry. The examination of determinants of long-run stock performance will give us some additional clues on this issue.

The signaling model of Perotti (1995) predicts that the higher the stake offered at the IPO, the more efficiency gains are expected. Thus, we may expect that stake sold is positively related to privatization returns. However, the price at which a competitive capital market will be willing to pay for the shares is affected by the anticipated degree of redistribution or policy uncertainty. The market is not willing to pay full economic price for the privatized shares until the credibility of the issuer or the government is built. If the market is efficient, a discount will be required to compensate for policy uncertainty, and the degree of 
underpricing should be positively related to the ex-ante volatility or risk measure. Ritter (1984) used standard deviation of 20 daily returns in the aftermarket as a proxy of ex-ante risk. We employ this ex-ante risk measure as a proxy for the policy uncertainty along with stake sold. In this paper, we investigate the privatization returns for each holding period by regressing the privatization returns on the signaling variables of Perotti (1995).

Beta, book-to-market ratio, firm size (defined as the logarithm of market value of a firm), and industry dummies are selected as the issue-specific factors. Since beta, book-to-market ratio and ex-ante risk are measures of risk, we may predict that they are positively related to privatization returns. As discussed before, La Porta et al. (1998) show that the origin of commercial law, together with an accounting standards index for a country is closely related to the performance of the economy. We employ law dummies and an accounting standards index for each country which is taken from La Porta et al. (1998). Univariate test results confirm that GNP per capita is a proxy for the corporate governance scheme of the economy. Mitchell and Stafford (2000) show industry factor matters. Therefore, accounting standards index, GNP per capita, and law dummies are included in the regression equation to examine the effect of the economy's institutional features on the aftermarket performance of issuers.

In sum, our multivariate regression equation shown in equation (3) is as follows: dependent variables are one-, three-, and five-year equally-weighted BHARs. The explanatory variables are two signaling variables (stake sold at initial offer (SS) and ex-ante risk measure (EAR)), four issue-specific variables (beta (Be), book-to-market ratio (BM), logarithm of firm size (FS), and industry dummies $\left(D_{n a}\right.$ for natural resources, $D_{f i}$ for financial firms, $D_{s e}$ for services, and $D_{u t}$ for utilities), and three economy-wide variables (accounting standards (AS), logarithm of GNP per capita (GNP), and law dummies ( $D_{e n}$ for English law, $D_{f r}$ for French law, $D_{g e}$ for German law, and $D_{s o}$ for Soviet law)).

$$
\begin{gathered}
\text { BHAR }=a+\beta_{1} S S+\beta_{2} E A R+\beta_{3} B M \\
+\beta_{4} B e+\beta_{5} F S+\beta_{6} A S+\beta_{7} G N P \\
\gamma_{1} D_{e n}+\gamma_{2} D_{f r}+\gamma_{3} D_{g e}+\gamma_{4} D_{s o}+\delta_{1} D_{n a}+\delta_{2} D_{f i}+\delta_{3} D_{s e}+\delta_{4} D_{u t}
\end{gathered}
$$

This type of multivariate regression enables us to further refine our tests by controlling several factors affecting the privatization returns. 
Coefficients are estimated by White's (1980) heteroskedasticiy-adjusted regressions.

Three sets of regression results are presented in table 5. All of the estimated equations are significant and show relatively good explanatory power. The findings tend to support the predictions of the signaling model. The estimated coefficients on stake sold have the predicted signs (i.e., positive). Perotti (1995) argues that the amount of stake sold signals potential risk of policy change and it serves to ensure success of privatization. Evidence presented by Perotti and Oijen (2001) that political risk resolves gradually is also consistent with the previous studies that privatization IPOs appear to outperform matched control groups (Megginson et al. [2000]). They attribute this result to the greater sensitivity of these stocks to political risk. They confirm that this effect vanishes after the IPO, as political risk gradually declines. Interestingly, the signaling variables (stake sold and ex-ante risk measure) are closely related to returns in the earlier post-IPO period, while issue-specific factors (beta, book-to-market ratio, firm size, and industry dummies) and economy-wide variables (accounting standard, GNP per capita and law dummies) become more important as the market experience increases. An implication of this is that the transfer of ownership from the public to the private sector contributes to an increase in the value of the privatized firm.

The test results show a statistically significant relationship between the ex-ante risk measure and privatization returns overall post-IPO period. The relationship is most strong in three-year holding period, but becomes less important explanatory variable later on. This is consistent with Ritter (1984) who found significantly positive relationship between IPO returns and proxies of uncertainty for the natural resource issues. Book-to-market ratio has little effect on privatization returns in the earlier period, while it becomes significant in the later period. Beta has significance in earlier period but becomes insignificant later on. Those findings tend to be consistent with the implication of Perotti's (1995) signaling model. That is, in the earlier period immediately following privatization the value of privatized shares is closely related to the political risk of the government. As the reputation of the privatizing government grows, however, conventional risk measures such as book-to-market ratio become more important in determining the market price of the privatized shares.

Brav and Gompers (1997) empirically show that overwhelmingly small, low book-to market ratio firms especially IPOs perform poorly, 
while large firms do not. The coefficient for the firm size is significantly negatively related to the holding period returns over one-, three-, and five-year period. This is not consistent with Brav and Gompers (1997) who report that large firms do not show underperformance in the longer-horizons. Possible explanations for this include that market discipline did not function well, or the market capacity was inadequate, in the case of large privatization IPOs offered in countries with less-developed capital markets (for example, PT Telkom of Indonesia and ENEL of Italy).

GNP per capita, a proxy for average corporate governance of the firms in the country, also contributes to privatization returns. Profitability improvement and efficiency gains are much higher in developed than developing countries. The coefficients for the accounting standards are insignificant and it appears that they have little effect on privatization returns. This is presumably because the privatization issues from countries with low investor protection and less stringent accounting standards tend to be listed on the thin local markets, and are not prone to market discipline. This implies that for privatization to yield better results it should be preceded by market reform to ensure investor protection. Ramamurti (2000) emphasizes the importance of a country's level of institutional development in determining the failure or success of a privatization program. Williamson (1996) also asserts that an economy will only get the price mechanism right if it establishes appropriate property rights and institutional features first.

IPO issues from English and German law based economies perform well while those from Soviet law based economies do not. French law may not contribute to profitability gains in the post-privatization regime. Industry dummies also explain the earlier performance of privatization shares in our regression equations. The estimated coefficients of the financial dummy are insignificantly negative in immediate post-IPO period, and remain negative. Coefficients of utility dummy are insignificantly positive in the first year, and then become significantly positive in the three-year holding period. They are economically insignificant in the five-year holding period, however.

The evidence presented here lends support to the implication of the signaling model that firms whose values are highly sensitive to public policy choices tend to be privatized with deeper discount. The capital markets require a discount for the anticipated policy uncertainty of the privatized firms, until the privatizing government builds up its 
TABLE 5. Determinants of BHARs of Privatization IPOs

\begin{tabular}{lccc}
\hline Dependent Variable & One-year & Three-year & Five-year \\
\hline Constant & -0.0387 & -0.5534 & -0.7712 \\
& $(-0.081)$ & $(-0.418)$ & $(-0.486)$ \\
Stake Sold & 0.2206 & 0.4506 & 0.4531 \\
& $(0943)$ & $(1.054)$ & $(0.730)$ \\
Ex-Ante Risk & 0.0706 & 0.0749 & 0.2454 \\
& $(2284 * *)$ & $\left(2.952^{* * *}\right)$ & $\left(2.499^{* *}\right)$ \\
Book-to-Market & 0.0365 & 0.0606 & 0.7349 \\
& $(0.348)$ & $(0.284)$ & $\left(1.869^{*}\right)$ \\
Beta & 0.3064 & -0.2054 & 0.4030 \\
& $(1750 *)$ & $(-0705)$ & $(0.645)$ \\
Firm Size & -0.1206 & -0.1192 & -0.5021 \\
& $\left(-1798^{*}\right)$ & $(-1.678 *)$ & $(-2.069 * *)$ \\
Accounting std & 0.0049 & 0.0083 & -0.0017 \\
GNP per capita & $(1.541)$ & $(0.746)$ & $(-0.130)$ \\
& 0.0465 & 0.0284 & 0.3016 \\
& $(0.817)$ & $(0.223)$ & $\left(1764^{*}\right)$ \\
\hline
\end{tabular}

(Continued)

reputation over time. As the credibility of the government grows the market begins to recognize the issue-specific factors such book-to-market ratio, as well as the increased performance of the privatized firm. This is also determined by the institutional features such as the origin of the country's commercial law and GNP per capita, a proxy for the corporate governance scheme of the economy. Thus, the evidence indicates that the abnormal returns of privatization IPOs might be explained by the risk and return framework of the signaling model in the earlier post-IPO periods, and by the traditional market factor such as book-to-market ratio and economy-wide variables such as origin of commercial law and GNP per capita in the later post-privatization periods.

\section{Conclusion}

This study investigates the long-run return performance of 241 privatization IPOs from 41 countries. It is one of the few multinational studies to have explored the determinants of performance changes for 
TABLE 5. (Continued)

\begin{tabular}{lccc}
\hline Dependent Variable & One-year & Three-year & Five-year \\
\hline English Law & 0.0755 & 0.5595 & 1.4239 \\
& $(0.426)$ & $(1.615)$ & $\left(3.138^{* * *)}\right)$ \\
French Law & 0.0856 & 0.4888 & 0.2835 \\
& $(0446)$ & $(1.103)$ & $(0.458)$ \\
German Law & 0.0904 & 0.6267 & 0.7991 \\
& $(0442)$ & $(1.773 *)$ & $(1.454)$ \\
Soviet Law & -0.0088 & 0.1522 & -1.2635 \\
& $(-0.026)$ & $(0.181)$ & $(-1.151)$ \\
Natural Ind. & -0.1087 & 0.2934 & 0.1869 \\
& $(-0.644)$ & $(0.793)$ & $(0.375)$ \\
Financial Ind. & -0.2262 & -0.2340 & -0.2533 \\
& $(-1600)$ & $(-1238)$ & $(-0.510)$ \\
Service Ind. & -0.2736 & 0.2590 & 0.2843 \\
& $(-1.302)$ & $(0.857)$ & $(0.345)$ \\
Utility Ind. & 0.0954 & 0.4743 & 0.5413 \\
& $(0670)$ & $(1.923 *)$ & $(1396)$ \\
F - value & $2.7393 * * *$ & $2.7844 * * *$ & $5.5299 * * *$ \\
Adj $R^{2}$ & 0.1552 & 0.1586 & 0.3348 \\
$\mathrm{~N}$ & 143 & 143 & 136 \\
& & & \\
\hline
\end{tabular}

Note: One-, three-, and five-year holding period buy-and-hold abnormal returns are regressed on Stake Sold, Ex-Ante Risk, Book-to-Market ratio, Beta, Firm Size, Accounting Standards, GNP per capita, five origin-of-law dummy variables, and five industry dummy variables. Stake Sold means the percentage of the firm's capital in the initial offer. Ex-Ante Risk is standard deviation of 20 daily returns in the aftermarket. Book-to-Market ratio, beta and firm size are obtained from Datastream International Information on law origin and accounting standard is taken from La Port et al. (1998). Industry classification is based on the two-digit standard industry classification code. Coefficients are estimated by White's (1980) heteroskedasticiy-adjusted regressions. The $t$-statistics are given in parentheses. $\mathrm{N}$ indicates the sample size. *, **, and ${ }^{* * *}$ indicate results are significant at 10 percent, 5 percent, and 1 percent level, respectively.

newly-privatized firms. There has been a general tendency for privatization IPOs to outperform their domestic capital markets, over a five-year holding period, if we equally weight the returns. However, value-weighting the abnormal returns of issuers reduces the measured abnormal performance to a level that is economically meaningless. These findings are consistent with those of Brav et al. (2000), Eckbo et al. (2000), and Mitchell and Stafford (2000). The results are robust to alternative abnormal return calculation methods.

There are two main contributions of this paper. First, this study 
shows that the differences in long-run returns are related to the extent of investor protection and the mechanism of corporate governance. Specifically, for privatization to yield better results, it should be preceded by market reform to ensure investor protection and market discipline. Secondly, this study also shows that privatization returns can be explained by the traditional risk-return framework. Stake sold and ex- ante risk are used as signaling variables; beta, book-to-market ratio, firm size, and five industry dummies as issue-specific variables; and accounting standards, GNP per capita, and five law dummies as economy-wide variables. Results from the multivariate regression analysis, controlling for industry characteristics, showed that signaling variables are closely related to the earlier post-IPO period, while issue-specific factors and economy-wide variables become more important as the market experience increases.

The test results support the implications of the signaling model. Higher returns for privatization IPOs are associated with higher ex-ante risk measure (the standard deviation of returns). Industry characteristics (utility dummy) also contribute to the explanation of the high BHARs of privatization IPOs. This effect appears to be overwhelming in the earlier post-IPO period, while the traditional market and economy wide factors become more important as the policy uncertainty disappears over time. Thus, the evidence indicates that the abnormal returns of privatization IPOs might be explained by the risk and return framework of the signaling model in the earlier post-IPO periods, and by the traditional market factors such as book-to-market ratio and firm size in the later post-privatization periods. The evidence also indicates the importance of a country's level of institutional development in determining the failure or success of a privatization program.

\section{References}

Alchian, A. A., 1965. Some economics of property rights. Il Politico: 816-829. Barber, B. M. and J. D. Lyon, 1997. Detecting long-run abnormal stock returns: The empirical power and specification of test statistics. Journal of Financial Economics 43: 341-372.

Boubakri, N. and J.-C. Cosset, 1998. The financial and operating performance of newly-privatized firms: evidence from developing countries. Journal of Finance 53: 1081-1110.

Boycko, M., A. Shleifer, and R. W. Vishny, 1996. A theory of privatization. Economic Journal 106: 309-319. 
Brav, A. and P. A. Gompers, 1997. Myth or reality? The long-run underperformance of initial public offerings: Evidence from venture and non-venture capital-backed companies. Journal of Finance 52: 1791-1821.

Brav. A., C. Geczy, and P. Gompers, 2000. Is the abnormal return following equity issuances anomalous? Journal of Financial Economics 55: 1791-1892.

Choi, S.-D. and S.-K. Nam, 1998. The short-run performance of IPOs of privately- and publicly-owned firms: International evidence. Multinational Finance Journal 2(3): 225-244.

Corwin, S. A., J. H. Harris, and M. L. Lipson, 2004. The development of secondary market liquidity for NYSE-listed IPOs. Journal of Finance 59(5): 2339-2374.

Dewenter, K. and P. H. Malatesta, 2001. State-owned and privately-owned firms: An empirical analysis of profitability, leverage, and labour intensity. American Economic Review 91(1): 320-335.

D'Souza, J. and W. L. Megginson, 1999. The financial and operating performance of Newly Privatized firms in the 1990s. Journal of Finance 54: 1397-1438.

Eckbo, B. E., R. W. Masulis, and O. Norli, 2000 Seasoned public offerings: Resolution of the 'new issue puzzle'. Journal of Financial Economics 56: 251-291.

Fama, E., 1998. Market efficiency, long-term returns and behavioral finance. Journal of Financial Economics 49: 1579-1593.

Jain, B. A. and O. Kini, 1994. The post-issue operating performance of IPO firms. Journal of Finance 49: 1699-1726.

Jones, S. L., W. L. Megginson, R. C. Nash, and J. M. Netter, 1999. Share issue privatization as financial means to political and economic ends. Journal of Financial Economics 53: 217-253.

La Porta R., F. Lopez-de-Silanes, A. Shleifer, and R. Vishny: 1998. Law and Finance. Journal of Political Economy 106(6): 113-1155.

Loughran, T., J. Ritter, and K. Rydqvist, 1994. Initial-public offerings: International insight. Pacific-Basin Finance Journal 2: 165-199.

Lyon, J. D., B. M. Barber, and C.-L. Tsai, 1999. Improved methods for tests of long-run abnormal stock returns. Journal of Finance 54: 165-201.

Megginson, W. L., R. C. Nash, and M. van Randenborgh, 1994. The financial and operating performance of newly privatized firms: An international empirical analysis. Journal of Finance 49: 403-452.

Megginson, W. L., R. C. Nash, J. M. Netter and A. L. Schwartz, 2000. The long-run return to investors in share issue privatization. Financial Management 29(1): 69-77.

Megginson, W. L. and J. M. Netter, 2001. From state to market: A survey of empirical studies on privatization. Journal of Economic Literature 39: 321389.

Mikkelson, W., M. Partch, and K. Shah, 1997 Ownership and operating 
performance of companies that go public. Journal of Financial Economics 44: 281-307.

Mitchell, M. and E. Stafford, 2000. Managerial decisions and long-term stock price performance. Journal of Business 73(3): 287-329.

Perotti, E.,1995. Credible privatization. American Economic Review 85: 847-859.

Perotti, E. and P. van Oijen, 2001. Privatization, political risk and stock market development in emerging economies. Journal of International Money and Finance 20: 43-69.

Ramamurti, R., 2000. A multivariate model of privatization in emerging economies. Academy of Management Review 90: 525-550.

Ritter, J., 1984. The hot issue market of 1980. Journal of Business 57: 215-240.

Ritter, J. R., 1991. The long-run performance of initial public offerings. Journal of Finance 46: 3-27.

Ritter, J. R. and I. Welch, 2002. A review of IPO activity, pricing, and allocations. Journal of Finance 57: 1795-1828.

Shleifer, A. and R. Vishny, 1997. A survey of corporate governance. Journal of Finance 52: 737-783.

Vickers, J. and G. Yarrow, 1988. Privatization: An Economic analysis. Cambridge, MA: MIT Press.

Williamson, O. E., 1996. The mechanisms of governance. New York and Oxford, Oxford University Press.

World Bank, World Development Report, Various issues. 